\title{
Adnexal bening tumor with deroupting dermoscopy
}

Khadija Elboukhari, Selma El Kadiri, Selma Benkirane, Fatima Zahra Mernissi

Department of Dermatology, University Hospital of Fez, Fez, Morocco

Corresponding author: Dr. Khadija Elboukhari, E-mail: elboukharikhadija89@gmail.com

Sir,

A 38 years old man presented a brown nodule on the face, which appears since childhood and was growing up 02 months before the consultation. It was painless and without pruritus. The dermatological examination showed a pigmented nodule, localized under the lower left eyelid. Dermoscopy showed typical ovoid nests and thick arborizing vessels (Fig. 1). In front of this clinic-dermoscopic appearance, pigmented basal cell carcinoma was evoked. After the nodule resection, histologic examination showed a proliferation of tumors connected to the epidermis, arranged in masses and made of regular cuboid cells presenting monomorphic nuclei with finely nucleated chromatin and an abundant basophilic cytoplasm. The tumor cells are pigmented and the mitoses were rare (Fig. 2).

Eccrine poroma is uncommon benign neoplasm first described by Pinkus in 1956 [1]. It originates from the terminal ductal portion of the sweat glands annexed to the skin, they commonly appear as a skin colored papules or nodules on the extremities [2]. Its pathogenesis may be secondary to trauma scars [3]. In our patient the facial location suggests the implication of UV radiations.

Although Blue-gray ovoid nests and arborizing vessels are known as a specific dermoscopic signs of Basal Cell Carcinoma, they have been found recently in dermoscopic features of pigmented eccrine poroma [4].

The eccrine poroma is recognizably distinct from the other eccrine duct tumors [5]. They are designated as benign lesions due to their lack of cytologic atypia and mitotic activity, as was found in our patient. The most described aspects of pigmented eccrine poroma is the proliferation of uniform cuboid cells with light-colored cytoplasm and evident intercellular bridges [2]. We can fond also hyperkeratosis, melanin granules and pigmented melanocytes like in our case.

\section{Consent}

The examination of the patient was conducted according to the Declaration of Helsinki principles.

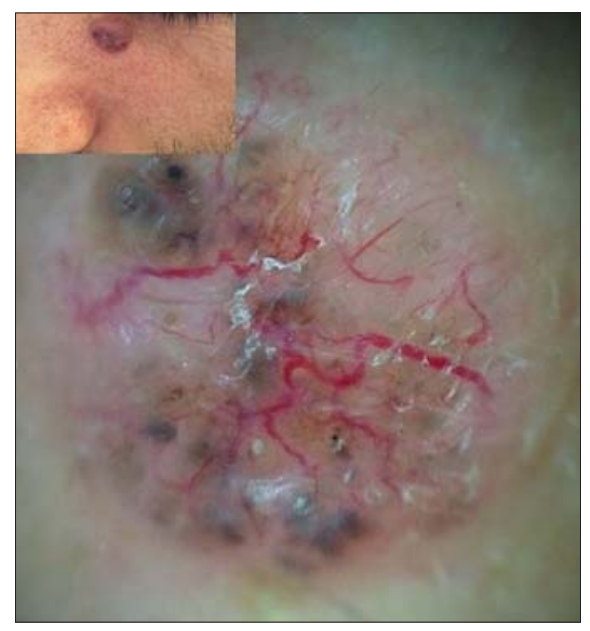

Figure 1: Dermoscopic image showing ovoid nets and arborizing vessels.

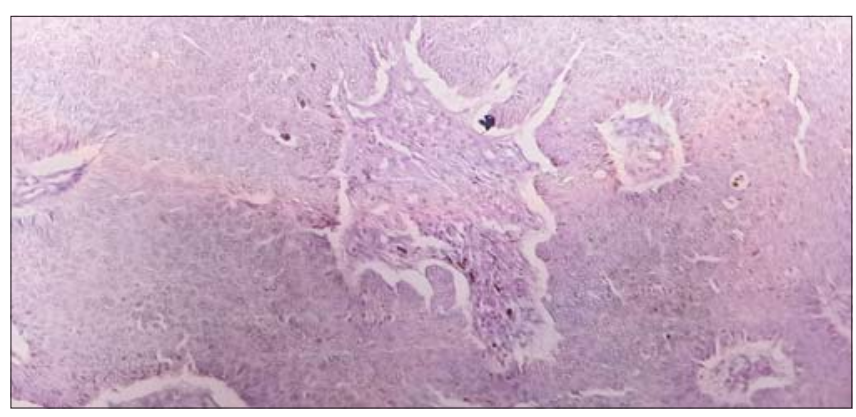

Figure 2: Cuboid cells proliferation with melanine granules and pigmented melanocytes, (HES Stain G x 100).

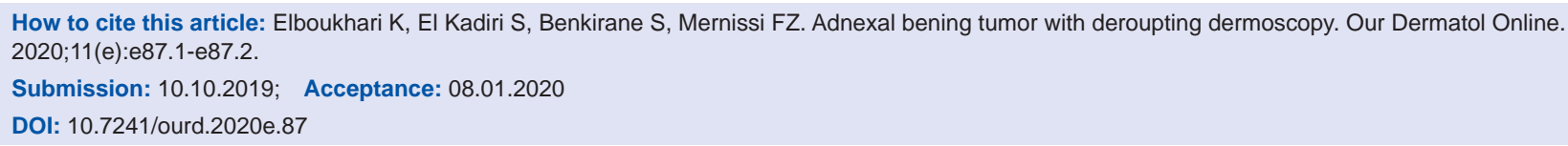


The authors certify that they have obtained all appropriate patient consent forms. In the form the patient(s) has/have given his/her/ their consent for his/her/their images and other clinical information to be reported in the journal. The patients understand that their names and initials will not be published and due efforts will be made to conceal their identity, but anonymity cannot be guaranteed.

\section{REFERENCES}

1. Goldman P, Pinkus H, Rogin JR. Eccrine poroma, tumors exhibiting features of the epidermal sweat duct unit. JAMA Arch Derm. 1956;74:511-21.

2. Marchetti MA, Marino ML, Virmani P, Dusza SW, Marghoob AA, Nazzaro G, et al. Dermoscopic features and patterns of poromas: a multicentre observational case-control study conducted by the
International Dermoscopy Society. J Eur Acad Dermatol Venereol. 2018;32:1263.

3. Lim GH, Abd Rashid F, Wong A. Eccrine poroma of the nipple: the first reported case. BMJ Case Rep. 2019;12:e228665.

4. Chessa MA, Patrizi A, Baraldi C, Fanti PA, Barisani A, Vaccari S. Dermoscopic-Histopathological correlation of eccrine poroma: An observational study. Dermatol Pract Concept. 2019;9:283-91.

5. Rafiei R, Eftekhari H, Daryakar A, Nickhah N, Rafiee B. Eccrine porocarcinoma: a case report and brief review of the literature. Our Dermatol Online. 2016;7:391-3.

Copyright by Khadija Elboukhari, et al. This is an open access article distributed under the terms of the Creative Commons Attribution License, which permits unrestricted use, distribution, and reproduction in any medium, provided the original author and source are credited.

Source of Support: Nil, Conflict of Interest: None declared. 